\title{
Territory incognita
}

DOI:

$10.1177 / 0309132519879492$

\section{Document Version}

Accepted author manuscript

Link to publication record in Manchester Research Explorer

\section{Citation for published version (APA):}

Usher, M. (2019). Territory incognita. Progress in Human Geography, 44(6), 1019-1046.

https://doi.org/10.1177/0309132519879492

\section{Published in:}

Progress in Human Geography

\section{Citing this paper}

Please note that where the full-text provided on Manchester Research Explorer is the Author Accepted Manuscript or Proof version this may differ from the final Published version. If citing, it is advised that you check and use the publisher's definitive version.

\section{General rights}

Copyright and moral rights for the publications made accessible in the Research Explorer are retained by the authors and/or other copyright owners and it is a condition of accessing publications that users recognise and abide by the legal requirements associated with these rights.

\section{Takedown policy}

If you believe that this document breaches copyright please refer to the University of Manchester's Takedown Procedures [http://man.ac.uk/04Y6Bo] or contact uml.scholarlycommunications@manchester.ac.uk providing relevant details, so we can investigate your claim.

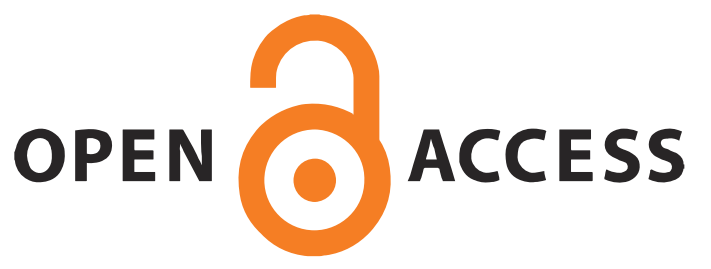


To cite this article: Usher, M. (2019) Territory incognita. Progress in Human Geography, DOI: $10.1177 / 0309132519879492$

\section{Territory incognita}

Mark Usher, University of Manchester

Tracing the lineage of territorial theorization, from legal container through dialectical, strategic and rhizomatic interpretations, this paper contends that more-than-human aspects of territory have been routinely circumvented by scholars seeking to avoid its realist, imperialist intellectual past. However, with the crisis of representation in political theory precipitated by the planetary ecological crisis, territory as a material entity has sprung alive again. This paper proposes that a reinvigorated materialist approach, informed by Deleuze and Guattari's writings on territorial assemblages as machinic, nomadic and affective, can offer a way out of the territorial trap, reclaiming nomos from its conservative, masculine heritage.

Political science has often formulated its principles without regard to the geographic conditions of states, but as a matter of fact.

(Semple, 1911: 51)

[A] juridical way of thinking is far different from geography. Jurists have not learned their science of matter and soil, reality and territoriality from geographers.

(Schmitt, 2003 [1950]: 37)

It is truly astonishing that the concept of territoriality has been so little studied by students of international politics; its neglect is akin to never looking at the ground that one is walking on.

(Ruggie, 1993: 174)

Thinking is neither a line drawn between subject and object nor a revolving of one around the other. Rather, thinking takes place in the relationship of territory and the earth.

(Deleuze and Guattari, 1994: 85) 
To cite this article: Usher, M. (2019) Territory incognita. Progress in Human Geography, DOI: $10.1177 / 0309132519879492$

I More-than-human beginnings

Published in 1897, Friedrich Ratzel's Politische Geographie ['Political Geography'] was the first comprehensive treatise of a derided subfield, rendered accessible to a broader social scientific audience. Ratzel (1882, 1891) produced works of what he termed 'anthropogeography', the title of two earlier volumes, which bridged geography and the social sciences in order to study the effects of the physical environment on social evolution. As a contemporary political economist observed, Ratzel's work demonstrated that society 'is not merely the result of conscious human effort' but the 'product of forces greater than those of human will' (Ripley, 1894: 322). And indeed, somewhat anachronistically, Ratzel has been described as a 'more-than-human geographer' (Barua, 2018; Klinke and Bassin, 2018: 54), as well as being founding father of political geography, which is curious given the subsequent divergence that occurred between these concerns. Most provocative was Ratzel's contention that the state had hitherto been conceived by scholars as if it existed 'in the air', detached from the 'land' upon which it stood (Anon., 1899: 171). A nation-state was inconceivable for Ratzel without an environmental basis, as this provides the material resource through which a community is sustained and the territory is cultivated. In Ratzel's organic theory of the state, the territory, in a physical, ecological sense, as Boden ['ground'], is even more important for statehood than its population, similar to any other creature dependent on a habitat for survival.

Given the evacuation of physical geographical concerns from territorial theorization over the course of the twentieth century, it is the contention of this paper that Ratzel's conceptualization of territory, rooted in a heterodox naturalist ontology, is more relevant today than it was when originally formulated. It is ventured that a revitalized materialist approach to territory, oriented towards the earth's attributes, processes and forces that exist in excess of the conscious and strategic will of humans, can provide a way out of the analytical limitations of the 'territorial trap' (Agnew, 1994). Indeed, what Latour (2017: 275) terms a 'crisis of representation' in rational political theory, precipitated by the planetary ecological crisis, has provided an opportune moment to revisit the abandoned more-thanhuman beginnings of modern geography, with the reverse intention of challenging rather than reinforcing the linkage between sovereignty and territory. Territory is not straightforwardly commensurate with statehood, it will be argued, but instead mediates between de jure and de facto sovereignty, enabling or curtailing the exercise of state power. When territory is conceived as a dynamic material substrate rather than fixed spatial extent, 
To cite this article: Usher, M. (2019) Territory incognita. Progress in Human Geography, DOI: $10.1177 / 0309132519879492$

the importance of cultivation, and the physical characteristics of the earth, becomes apparent, in addition to borders and enclosure.

The paper will first elucidate how physical geography was originally considered an integral component of territorial theorization before this field of inquiry became toxified by imperialist thinking. Subsequently, the paper contends that prevalent strands of theorization, referred to here as legal, dialectical, strategic and rhizomatic, have routinely circumvented and disregarded the physical basis of territory. The final section will outline a future research agenda that builds on the unfolding material turn in territorial theorization and political theory more broadly (Bennett and Joyce, 2010; Braun and Whatmore, 2010). The critical import of Deleuze and Guattari's geophilosophy will be emphasized, specifically their conceptualization of territory as machinic, nomadic and affective, which can reclaim the notion of nomos from its masculine, realist heritage. Not only would such an agenda reassert the importance of geographical methods for interrogating territory, integrating once again physical and political concerns, it could potentially open the field to more diverse voices, within new materialism in particular, putting Ratzel's unconventional antiWestphalian analytics to alternative, more progressive ends.

Certainly, Ratzel advanced a number of original theoretical propositions based on cuttingedge findings from zoology, botany and geology, which he applied to questions of state and territory. The whole theoretical edifice rested on a central assumption, however, that 'space is the very first condition for life', leading to constant 'tension between the movement of life, which never rests, and the space on earth, which does not change' (Ratzel, 2018 [1901]: 72). This was a form of spatial rather than environmental determinism, whereby national communities, determined by shared territory rather than ethnicity, compete against one another in a Darwinian zero-sum struggle for finite space. Without a constantly increasing space, a state is not be able to increase its population, which for its survival necessitates room ['Raum'] for dwelling, food and manoeuvring, leaving the most vigorous states to flourish and weaker ones to suffer 'national decay' (Ratzel, 1898a: 451). It was the spatial aspect of Ratzel's theory that proved most influential, and fateful, in respect to how it naturalized territorial expansion as a biological drive, equating the migration of spiders on airborne webs, and polar bears on floating ice, with that of imperialist states.

However, the most original and neglected component of Ratzel's argument is not the spatial aspect, which, like most theorization of territory is essentially concerned with areal extent, but the materialist, ecological interpretation of statehood. According to Ratzel, state 
To cite this article: Usher, M. (2019) Territory incognita. Progress in Human Geography, DOI: $10.1177 / 0309132519879492$

territorialization occurs not only through imperialist spatial struggle but rootedness to the natural environment; territory is an ecological as well as spatial entity. This diverges from the conventional interpretation of territory as a fixed space of law, calculation and violence in a number of analytically significant ways. First, one must 'take into account the earth as a whole' when examining a given territory, where 'telluric' particularities differ from country to country based on location, quality of environment and stage of development (Ibid: 60). To approach territory as an abstract container, as in mainstream political theory, is to equate diverse territorial contexts and ignore the varied importance of physical attributes in statebuilding. Second, territory does not exist de jure but must be colonized, cultivated and engineered into existence through the physical working of the land. Environmental attributes can make a given territory more or perhaps less amenable to cultivation and sovereign control, from coal deposits to soil quality.

Third, territorialization is constitutive not only of the land but the people that facilitate its physical transformation into a 'living space' (Ratzel, 2018 [1901]: 71); the agriculturalists, engineers, and settlers that colonize its breadth. Ratzel (1898a: 452) referred to territory as a 'system' linking soil and people, geopolitics and biopolitics (see Klinke, 2018). To have a 'grasp on the soil' (Ratzel, 2018 [1901]: 75), implying a material-ecological rather than spatial relation, requires a dynamic and committed population, more so than sovereignty, law and violence. Ratzel identified the frontier spirit of the European settlers in North America as an example of how territory expands through population growth and technology such as roads, rail and telegraph. For Ratzel, national culture is shaped through connection and adaptation to the natural environment, where the larger the territory the broader the 'mental horizon' of the population (Ratzel, 1898b: 373). Emphasizing the affective quality of territory, which remains undertheorized in modern political geography even today, Ratzel (1898a: 457) insisted the 'larger their territory, so much the more diverse is their contact with nature'.

II From determinism to idealism

It was Ratzel's unique blending of contemporary political and ecological thinking that produced such an original, complex and multi-faceted conceptualization of territory, which initially had far-reaching impacts in and beyond his specialism of political geography. Ellen Churchill Semple, an influential American geographer, sought, with Ratzel's approval, to translate, develop and propagate his writings. Semple's (1911: vi) most famous work, Influences of Geographic Environment, on the Basis of Ratzel's System of Anthropogeography, was the most coherent restatement of Ratzel's theory for the 'Anglo- 
To cite this article: Usher, M. (2019) Territory incognita. Progress in Human Geography, DOI: $10.1177 / 0309132519879492$

Saxon mind'. Indeed, Semple's book provided a disciplinary baseline for American geography and arguably inspired the next generation of geographers more than any other work, significantly influencing the methodological and pedagogical development of geography in Britain (Keighren, 2006). Semple developed and nuanced Ratzel's materialist analysis of territory, while discarding with his more contentious ideas on the organic state. What emerged was an idiosyncratic and strikingly heterodox ontology of territory 'fundamentally at odds' to that of the classic Westphalian model that underpinned most political theory in the twentieth century (Bassin, 1987: 450).

At the centre of this ontology was the natural world; the physical, dynamic earth itself, not the geometric lines drawn upon it. For Semple (1911: 51), the 'question of territory' was an example of humans' presumption of mastery and conscious will over nature, which functions, legally and practically, as if the earth's surface was a blank, inert canvas, as 'mere area in contrast to specific geographic conditions'. In contrast to historians and social scientists that 'treat man [sic] as if he were in some way detached form the earth's surface', Semple conceptualizes territory as the 'underlying material bond holding society together, the ultimate basis of their fundamental social activities... an integrating force' (Ibid: 53). Following a distinctly Ratzelian logic, Semple argued that territory is not a fixed areal space of sovereignty defined by a surrounding boundary but a dynamic socio-ecological system that contracts and expands organically with the growth, migration and industry of a population, which is, as a consequence, metabolically and spiritually connected to the cultivated land. The more thoroughly and complexly a community is rooted in the earth, 'grown into every foot of its own soil' (Ibid: 53), through habitation, transport, agriculture and other forms of specialized land use, the more organized, mature and stable the nationstate. Territory is here defined in an environmental, civil register, as a dynamic, material substrate rather than a fixed bounded space, restricted not by an 'imaginary line' (Ibid: 191) but lack of spirit and vitality in the population.

In retrospect, this critique of the Westphalian model of territorial sovereignty, which still remains dominant today, anticipated the material turn in territorial theorization a century later (Clark and Jones 2017; Peters et al, 2018; Squire 2016). However, although some deemed it the most notable work published in English on the 'influence of natural conditions on human history' (Chisholm, 1912: 31), it was widely criticized as simplistic and sweeping by leading social scientists, disregarded as an example of a discipline overreaching itself (Koelsch, 2014). Most problematically, environmental determinism, which Semple introduced to mainstream geography via Ratzel's work, was already falling out of favour by the second 
To cite this article: Usher, M. (2019) Territory incognita. Progress in Human Geography, DOI: $10.1177 / 0309132519879492$

decade of the twentieth century. Not only was it deemed crude but it provided a theoretical basis for European and American colonization of apparently undeveloped, "less rational" peoples in warmer, tropical climates (Frenkel, 1992; Peet, 1985). Consequently, it is Semple's toxic association with environmental determinism, rather than her sustained development of Ratzel's materialist conceptualization of territory, which has become her legacy. Their work has been written out of geography's intellectual history as a result, deemed taboo and a 'false start' (Harden, 2012; Turner, 2002: 58; Zimmerer 2010).

While Ratzel's reputation had become tarnished by determinism, his anti-Westphalian theory of territory would find analytical purchase in the nascent field of geopolitics. Halford Mackinder, 'father of geopolitics' (Kearns, 2009: 6) and modern British geography, was strongly influenced by Ratzel's thinking on territory, providing an alternative conduit for his ideas (Ashworth 2010). Mackinder (1887: 143) affirmed in his manifesto for a 'new geography' that 'no rational political geography can exist which is not built upon and subsequent to physical geography'. Echoing Ratzel, Mackinder called for interdisciplinary research on the 'physical basis of political geography' (Mackinder, 1890: 78), specifically the 'resistance' and 'facilities' of nature on human migration and settlement (Ibid: 79). This informed Mackinder's (1904) notorious theory of the 'Heartland', an area encompassing Russia and Central Asia, which he considered a 'natural seat of power' given its geographical location, being protected from naval assaults and connected by transcontinental rail. Couched in realist terms, Mackinder railed against the 'narrow legalism' that prevailed in the aftermath of the First World War, and urged Western statesmen to act as 'administrators' rather than as 'idealists', and formulate strategy sensitive to the material forces of environment (Knutsen, 2014: 838).

Remarkably, the opposite occurred in the theorization of territory as scholars sought to avoid the deterministic, increasingly realist baggage of political geography and geopolitics. A conservative bias was soon evident in these emerging fields, and a preoccupation with state interests (Bassin, 2003; Claval, 2006). Indeed, what united these early geographers, Ratzel, Mackinder and Semple, was not only their unique materialist analysis of territory but a shared commitment to imperialism, lending it a peculiarly scientific, ecological veneer (Cowen and Smith, 2009; Farinelli, 2000). Mackinder incorporated environmental determinism into an explicitly realist framework, which had been latent and suggestive in the work of Semple. The geographical theory of Ratzel and Mackinder was combined as a 'weapon' for conservative forces, most notoriously in the ideology of National Socialism via 
To cite this article: Usher, M. (2019) Territory incognita. Progress in Human Geography, DOI: $10.1177 / 0309132519879492$

Karl Haushofer and Rudolf Kjellén. Ratzel's concept of Lebensraum ['living space'] became the most potent of geographical concepts mobilized by the Nazi regime (Keighren, 2018).

As Klinke and Bassin (2018: 53) affirm, Ratzel has become a 'disgraced figure' as a consequence. Yet, his ontology of territory remains theoretically significant today, arguably even more so. Modern political geography developed in conscious opposition to Ratzel's pseudo-scientific theory of the state, with attention turning away from environmental features to legal arrangements, economics and national culture, particularly in France, a victim of imperialism (Parker 2000). It is therefore not quite correct to suggest that Ratzel's writings on the nation-state provided the template for research in political geography (Dodds, 2000), as his materialist conceptualization of territory, as a dynamic environmental substrate, was comprehensively rejected. Certainly, by the end of the twentieth century, many of the darker elements of political geography had been expunged by geographers seeking to reclaim geopolitics from realism (Mamadouh, 1999). Interest in Ratzel has also increased, initiating a hesitant reappraisal and rehabilitation of this neglected geographer (Bassin 1997; Halas, 2014; Keighren, 2018; Klinke, 2018; Klinke and Bassin, 2018; Verne, 2017). Nevertheless, as it will now be demonstrated, subsequent theorization of territory has consistently overlooked, indeed, actively circumvented, the earth itself to avoid this realist yoke, leading to shift in territorial theorization from materialism to idealism, environment to space.

III Pushed to the edge

Indeed, for over four decades, an objection has been made by political geographers that territory as a concept has been increasingly taken for granted and undertheorized as a complex, material entity (Antonsich, 2009; Cox, 1991; Elden, 2013a; Gottmann, 1973; Painter, 2010; Sack, 1983). Modern state theorization has tended to neglect or underplay considerations of spatial and environmental dimensions, where state spatiality has been implicitly conceived as fixed and self-evident (Agnew, 1994; Brenner et al., 2003). In mainstream political theory, particularly international relations studies, territory has been conceptualized as a historical legal product of the Peace of Westphalia agreed between European kingdoms and estates in 1648 (Croxton, 1999). The treaty purportedly provided the beginnings of a legal apparatus for the coordinated division of the earth's surface into the modern state system of fixed borders and exclusive internal sovereignty, based on the norm of non-intervention in domestic affairs (Elden, 2009). 
To cite this article: Usher, M. (2019) Territory incognita. Progress in Human Geography, DOI: $10.1177 / 0309132519879492$

However, not only has the causal link between the Westphalia treaty and the notion of bounded territorial sovereignty been considered a simplified and convenient exaggeration (Teschke, 2003), this orthodox conceptualization of territory has precipitated a legalistic, binary and narrow preoccupation with political enclosure (Agnew, 2005; Steinberg, 2009). Over fifty years ago, for instance, Minghi (1963: 407) declared that boundaries that 'form the areal expression of the limits of jurisdiction...are perhaps the most palpable political geographic phenomena'. Consequently, the material guts of territorial space have been violently eviscerated by an abstract legal theorization set within a geometric spatial framework, edging ever further away from determinism and materialism. And despite the growing sophistication of border studies (Brown, 2010; Mezzadra and Neilson, 2013; Nail, 2016; Newman, 2003), territory continues to be conceptualized primarily in terms of political delimitation and legal enclosure, gravitating from the middle towards the 'ends of the state' (Anderson, 1996: 1).

Furthermore, this dualistic focus on borders has produced a false ultimatum, where the state is either being rolled back or rolled forward, eviscerated or consolidated (Allen, 2011; Shah, 2012). As analysis shifted from the physical middle to the geometric edge, a contested thesis of state decline has persisted through the twentieth century. Herz (1957: 487) prematurely proposed over sixty years ago that the territorial state, existentially characterized by impermeable boundaries, was in rapid decline due to the advent of air and atomic warfare. Here, the territorial state is effectively defined and legitimized by its ability to affect enclosure against external forces, processes and flows (Taylor 1994). In this overstatement of state decline, outer boundaries are given precedence over domestic, physical territorial space, indeed, over territory itself, evidenced by its subsequent disappearance with those of its borders. Compounding this, a methodological preoccupation with borders in political science and philosophy has served to reify a system of territorially enclosed, mutually exclusive nation-states as basic units of analysis, referred to as 'embedded statism' (Taylor, 2000) or 'state-centrism' (Brenner, 2004).

With his influential critique of the 'territorial trap', which now appears somewhat quaint after subsequent waves of relational and poststructural theory, Agnew (1994) precipitated a progressive analytical unbundling of Westphalian bordered territory. However, the physical world became even further marginalized in this unbundling process, particularly in postmodern theorization. This is most clearly detected in the burgeoning, epochal literature on transborder flows and related processes of deterritorialization under globalization, epitomized by Scholte's (2008) ethereal notion of 'supraterritoriality', but also in critical 
To cite this article: Usher, M. (2019) Territory incognita. Progress in Human Geography, DOI: $10.1177 / 0309132519879492$

geography (Amin, 2002; Smith, 2003). Bauman (2003: 19) identified the increasing obsolescence of territory in the globalized economy, depicting a similarly dematerialized world that 'is no-place, no-land, no-territory'. At its pithiest, Appadurai (1996) has contemplated 'sovereignty without territoriality', prompting Tuathail (1999: 139) to wryly comment '[i]nstead of soil, we will have software'. Similarly, Flint (2003: 619) warns against postmodern analyses of territory that lack 'consideration of the existing geography of sovereign nation-states, the terrain over which networks are established'.

IV The juridical/physical divide

As Foucault (2003: 270) frequently reiterated throughout the 1970 s, political analysis has conventionally prioritized abstract 'philosophico-juridical' concerns of sovereignty, overvaluing legal authority for interpreting relations of power. The strategic model that Foucault articulated decentred the unitary representation of the state, the 'king in his central position' (Ibid: 27), revealing instead the logistical and infrastructural underbelly of political sovereignty. Consequently, in Foucault's (2007) Security, Territory, Population lectures, territory is interpreted not as a rigid container of legal sovereignty but as a dense, complex and dynamic network of social, technical and environmental relations. As Foucault (2007: 23) proposed, the 'sovereign deals with a nature, or rather with the perpetual conjunction, the perpetual intrication of a geographical, climatic, and physical milieu with the human species'. Yet, Foucault did not provide a sustained engagement with the concept of territory along this materialist trajectory, to the point where it seemingly drops out of his analysis (Elden, 2007).

Indeed, the 'model of Leviathan' that Foucault (2003: 34) insisted political analysis should 'abandon' provides the basis for the spatio-legal interpretation of territory that still prevails today, which has its roots in the 'originary spatialization' (Agamben, 1998: 111) of a legal threshold between city and its hinterland. The dualistic binary in Greek philosophy between nomos and physis, law and nature, has provided a constant touchstone for political theorists, resulting in the dichotomization of an abstract juridical order and the concrete physical world (Mitchell, 2002; Schmitt, 2003). Elden (2013a) traces the modern concept of territory to fourteenth century Italian jurists Bartolus and Baldus, who detached it from the earlier, agriculturally inflected precursors of the Greek khora and Roman territorium, redefining territory as a legal geometric space. Similar to Ratzel's Lebensraum, these earlier terms denoted a natural hinterland and resource base rather than a bordered juridical zone, which sustains and shapes a community through its connectedness to land. Perhaps most influential has been Thomas Hobbes's theory of Leviathan, however, which is founded on 
To cite this article: Usher, M. (2019) Territory incognita. Progress in Human Geography, DOI: $10.1177 / 0309132519879492$

the sharp binary division between the common-wealth and its surrounding hinterland, where the 'city or state must pull away from nature to form itself at the same time as being grounded in nature to motivate and to legitimate it...[t]he city defines itself against nature in this sense' (Brett, 2011: 5).

This juridical conceptualization of territory, where it functions as a secondary medium to that of sovereign law, was central to Max Weber's (1978: 54) definitive formulation of the state as a political organization that 'upholds the claim to the monopoly of the legitimate use of physical force', which is 'claimed as binding within a territorial area' (55). Weber, a sociologist that trained principally as a jurist it should be noted, has in turn acted as a key analytical conduit for much contemporary theorization of territory, directly influencing Giddens's (1985) now classic 'power container' metaphor, Anderson's (1979: 29) historical materialist account of modern state formation through 'juridical modernization', and Bourdieu's (2014: 223) understanding of nomos as facilitating 'symbolic violence' over a 'unified and homogenous space'. This spatio-legal schema, or 'Weberian ideal' (Caporaso, 1996: 34), where territory figures in the second order as a bounded legal space, continues to dominate political science and international relations (Agnew, 2010; Häkli, 2001). As van Houtum (2005: 676) suggests, contemporary analysis of territory is 'still haunted by the by the Hobbesian ghost of (state) borders'.

Jean Gottmann (1973) was arguably the first theorist to offer a more sophisticated, relational account of territory. Gottmann argued that territory is not straightforwardly commensurate with legal sovereignty but embedded within a complex set of relational variables- technological, environmental, economic and political- where areal control has become less important in the contemporary era of global integration. While Gottmann (1973: ix) did recognize that territory was a rooted in a 'material...natural setting', physical matter and form were seen as secondary to human psychology, symbolism and experience, always 'delimited by human action' (Gottmann, 1975: 29). This prompted Gottmann to suggest that a frozen landscape has little immediate strategic value for humans, which, as is increasingly acknowledged in contemporary political geography, overlooks the more-than-human dynamism of the physical environment (Gerhardt et al., 2010). Gottmann was professionally committed to disproving the theory of environmental determinism, as were other leading geographers (Solot, 1986), resulting in a somewhat lopsided theorization of territory that privileged cultural 'software' over material 'hardware' (Muscarà, 2005). This reflexive antipathy to 'simplistic materialism' (Gottmann, 1947: 12), which had tarnished earlier 
To cite this article: Usher, M. (2019) Territory incognita. Progress in Human Geography, DOI: $10.1177 / 0309132519879492$

geographical research, would itself continue to delimit territorial theorization for the next three decades.

$\checkmark$ The strange elusiveness of territory

It was during the 1970s that a relational spatial ontology began to influence and eventually transform Anglophone human geography, overturning the conventional understanding of territory. Shifts in theorization on territory have been expressions of broader 'turns' in geography, progressing sequentially from absolute, through relative, into relational and topological conceptualizations of space (Jones, 2009; Martin and Secor, 2014). While the 'tussle' between absolute and relative space has been ongoing since the mid-nineteenth century (Harvey, 1969), the philosophical ideas of Foucault, Henri Lefebvre, Gilles Deleuze and Félix Guattari began to infiltrate mainstream geography in the 1970s, popularizing a relational ontology. Conceiving space relationally mounts a serious if not terminal challenge to the longstanding Westphalian container analogy of territory, which had survived largely intact from an earlier confrontation with Ratzel and Semple. What could be termed dialectical, strategic and rhizomatic perspectives have increasingly turned to the internal complexity of territory, prompting more sophisticated interpretations of taken-for-granted spatial forms such as boundaries and surfaces (Mol and Law, 2005). While territorial theorization has greatly benefited from the relational conceptualization of space, it could be argued that scholars have avoided one trap only to fall into another, a 'non-territorial trap' (Jones, 2009: 494). As dell'Agnese (2013) has ventured, whereas spatial fetishization was the analytical snare identified by Agnew, the challenge posed by relational thinking is not to vanquish territory altogether. Notwithstanding the enhanced complexity of theorization, the physical world has continued to be marginalized by concerns of capitalism, strategy and networks, which will now be considered in turn.

\section{Dialectical}

Alongside Foucault, Deleuze and Guattari, the Marxist philosopher Lefebvre has been key in exporting the relational perspective from Francophone to Anglophone theorization of territory (Murphy, 2012). Lefebvre (1991) strongly criticized the geometrical notion of absolute space that prevailed in the humanities and social sciences, which he dismissed as positivist, figurative and detached from the concrete physical world. Instead, Lefebvre situated capitalist production at the centre of his general theory, which produces space through the logic of accumulation and crystallizes relations of exploitation. For Lefebvre, space is inherently social, a physical yet temporary and constantly transmogrifying materialization of relations of production, a contested process rather than a measurable 
To cite this article: Usher, M. (2019) Territory incognita. Progress in Human Geography, DOI: $10.1177 / 0309132519879492$

thing. This prompted Lefebvre to describe space as a 'flaky mille-feuille pastry' (Ibid: 86), which, pertinent to territorial theorization, 'is neither a mere "frame"...nor a form or container of a virtually neutral kind, designed simply to receive whatever is poured into it' (94). Lefebvre advocated a dialectical approach that seeks to uncover embedded social relations in spatial formations, from urban centres and rural hinterlands to larger territorial and geopolitical configurations. As Marx intended for the commodity form, Lefebvre sought to defetishize the spatial condensation of the city, revealing how capitalism persists through the production of space.

Lefebvre's (2003, 2014) insistence on social over mathematical space has indelibly transformed how critical scholars approach the urban, which is recast as a contested process of struggle (Kipfer et al., 2013). However, when it comes to the concept of territory, the more-than-human dynamism of the natural world is significantly downplayed as a consequence of the dialectical approach. According to Lefebvre (1991: 48), the representational holds sway over the ecological in the production of spatial forms, to the point where the latter has been increasingly stripped of its 'natural characteristics and uniqueness'. The negation of nature under capitalism is a reoccurring motif throughout The Production of Space, at one point being considered to have 'disappeared altogether...[as] "elements" lose their natural determinations' (329). This stripping of the natural environment has occurred through the coordinated expansion of what Lefebvre calls 'abstract space' under the capitalist state, which violently homogenizes, categorizes and instrumentalizes territory. Abstract space is a fundamental bridging concept for Lefebvre between his concerns with spatial planning, the state and everyday life, denoting the alienation of human subjects from their material surroundings through the repurposing of space for commodity production (Loftus, 2015; Wilson, 2013). For Lefebvre (2009: 124), the most significant development of the twentieth century was the consolidation of the 'state mode of production', and its territorialization through industrial urbanization.

In contrast to legalistic 'container' interpretations, Lefebvre's theorization of statehood in The Production of Space and four volumes of De /'État provide a nuanced dialectical perspective on territory as processual, unstable and prone to transformation through institutional scalar reorganization (Charnock, 2010). And certainly, Lefebvre's dialectical understanding of space has exerted a profound influence on contemporary theorization of territory, particularly in respect to the politics of rescaling, even though he never identified as a theorist of territory (Agnew, 1994; Brenner, 2004; Brenner et al., 2003; Jessop, 2008; Jessop et al., 2008; Swyngedouw, 1992, 2000). Most notably, Brenner (2004), one of the 
To cite this article: Usher, M. (2019) Territory incognita. Progress in Human Geography, DOI: $10.1177 / 0309132519879492$

most persuasive critics of 'container' methodological territorialism, has drawn heavily on Lefebvre to shift territorial theorization away from a 'narrow' preoccupation with national borders to 'integral' spatial strategy based around the rescaling of governance (see also Brenner et al., 2003). For Brenner, the intention is to denaturalize territory, dialectically, by highlighting the process through which successive rounds of deterritorialization and reterritorialization occur across multiple geographical scales. As Claval (2006: 218) affirms, under Lefebvre's influence, scale came to be framed as a 'social construct' in political geography, not a 'property of the earth's surface'.

Consequently, in attempting to bridge the gap between the theory and practice of space by examining its social production under capitalism, Lefebvre effectively allows the earthly, more-than-human world to drop out of the bottom of his analysis. This is mainly a consequence of Lefebvre's application of 'abstract space' to territorial processes, which is space that has been 'emptied of its substantive content' (Wilson, 2014: 519). In its ability to evacuate difference from its extent to produce quantifiable, homologous space, territory becomes something of a non-place on a national scale, characterized by absence and lack; the state 'rules an empty order animated only by that which it negates' (Lefebvre, 2009: 250). Territory as abstract space is placed in opposition to the physical environment, it becomes 'anti-nature' (Lefebvre, 1991: 71). The embeddedness of territory in the physical world is therefore underplayed in the derivative literature oriented around Lefebvre's scalar morphology, where materialism is understood in the Marxist sense as economically determined spatial configurations (Cox, 2003; MacLeavy and Harrison, 2010). Indeed, there is an implicit geometry at work in the scalar interpretation of territory, which Amin (2002: 388) describes as an 'ontological straightjacket'. Not only is the elasticity of scale stretched to breaking point to capture the institutional complexity of contemporary statehood (Allen and Cochrane, 2010), territory as a bounded unit is only relativized across multiple jurisdictional levels or 'containers' rather than abolished, retaining an underlying geometric framework. Although there have been attempts to embed this scalar conceptualization within a broader constellation of jostling spatial dimensions, encompassing territory, place and networks (Jessop et al., 2008), serious consideration of the physical world in processes of territorialization is constantly eclipsed by the social production of space.

\section{Strategic}

Foucault $(2007,2008)$ delivered his research on the state during precisely the same period as Lefebvre, between 1976 and 1978, which included his most explicit engagement with territory. However, in comparison to Lefebvre's overarching analysis of the centralized 
To cite this article: Usher, M. (2019) Territory incognita. Progress in Human Geography, DOI: $10.1177 / 0309132519879492$

Fordist state, pulverizing, standardizing and cataloguing territory, Foucault would move beyond his analogous critique of disciplinary space and begin to develop a suppler analytics of government. In contrast to the disciplinary form of power, which violently divides space into a grid-like arrangement, mechanisms of security function instead through the centrifugal management of circulation. Neoliberalism, the 'other face' (Foucault, 2008: 65) of security, intends to adapt to the autonomy of social and ecological processes by identifying and optimizing the discernible proclivities of nature. As Foucault (2007: 75) contended, against the 'cold monster' depiction of the state then prevalent in Marxist theory, the 'sovereign must deploy reflected procedures of government within this nature, with the help of it, and with regard to it'.

As part of this analytical reassertion of nature in political theory, Foucault emphasized the environmental 'qualities' of territory, which have a capacity to mediate, shape and augment governmental strategy. Territory was not a passive imprint of capitalist logic but a strategic, environmental medium for broader processes of calculation and the biopolitical management of the population. Physiocracy, an economic theory developed by a group of French economists in the eighteenth century, was drawn upon by Foucault (2007) to illustrate the increasingly complex, dynamic conceptualization of territory characteristic of the contemporary modern era. Physiocratic economics, which translates into English as 'government of nature', sought to shift the emphasis of state policy from gold and trade to agriculture and soil, positing that the development of land, the physical environment, was the source of national wealth and security. The physis is not opposed but fundamental to modern forms of politics, '[n]ature...is, if you like, its indispensable hypodermis' (Foucault, 2008: 16).

Nevertheless, Foucault did not undertake a sustained analysis of territory as his studies turned towards biopolitics, leaving this field of inquiry to lie fallow. Given the delay in translation of these lectures, the disciplinary conceptualization of power has until recently predominated in derivative theorization of territory, privileging the abstract, mathematical and visual over the vibrant and materialist (Philo, 2012). Rutherford (2007: 294) goes as far as to suggest that '[n]ature was never high on Foucault's list of priorities...nature was rarely included in Foucault's analyses'. Therefore, theorization of territory that draws on Foucault tends to reflect this extraction of the natural from the political, which the philosopher had in fact sought to assimilate. As with the dialectical interpretation, the material-ecological register has been deprived of any serious form of effect, agency or quality outside of immediate strategic and calculative concerns. Most notably, based on Foucault's earlier work 
To cite this article: Usher, M. (2019) Territory incognita. Progress in Human Geography, DOI: $10.1177 / 0309132519879492$

on discipline, Sack (1986: 19) conceives of territoriality as the 'attempt by an individual or group to affect, influence, or control people, phenomena, and relationships by delimiting and asserting control over a geographic area'. Through the enclosure of space, human actors exert, depersonalize and reify their ability to control human processes and achieve strategic outcomes. While Sack developed a relational conceptualization of territory, arguing that it is produced through human practice rather than existing as a static legal object, territory is reduced to being a tractable intermediary, a secondary effect of strategy, lacking geographical and historical definition (Delaney, 2005). For Sack (1983: 59), territory creates the impression of an 'empty space' and 'conceptually separates space from things'.

The historian Charles Maier (2016: 1), drawing on the work of Foucault, scrutinizes territory in a Sackian fashion as a delimited geographic space, 'empowered by borders', enabling of decision-making, taxation, warfare and governance. For Maier, 'this must be an inquiry into political space, not a history of landscape or natural environment' (6), thus perpetuating the originary spatialization between the physical and juridical registers. As a consequence, again, territory acts as a necessary 'spatial foundation' (8) of sovereignty, passive and inertly facilitative of state power, without ever seemingly enjoying an existence of its own with a capacity to influence and possibly even delimit the exercise of sovereignty. The highly influential work of Scott (1998: 3) is premised on an analogous interpretation of territory as a technical product of cartographic geometric simplification, facilitative of top-down interventions and centralized state control through enhanced legibility. Inspired by Foucault's writings on disciplinary space, nature is again cast as the 'resource' of state administration, geometrized, catalogued and pacified (Scott, 1998: 15; Vela-Almedia, 2018).

This Sackian depiction of territory as an abstract representational device for enabling and expediting processes of government through technical methods of calculation has been refined most compellingly by Elden (2010a, 2013a), which he proposes can be approached as a 'political technology'. For Elden, territory is a mode of spatial organization made possible through technical advancements in analytic geometry, land surveying and cartography, allowing for the control of territorial space through mathematical calculation and legal mechanisms. This calculative conceptualization of space not only made the material world amenable to quantitative measurement and administration but established the conceptual underpinnings of a bordered territory, and indeed, the modern nation-state. In human geography in particular, the link between calculation and territory has been become subject to sustained scrutiny, from Nazi Germany to Colonial India (Elden, 2006; Legg, 2007), embedding a calculative reframing of the political in critical geographical 
To cite this article: Usher, M. (2019) Territory incognita. Progress in Human Geography, DOI: $10.1177 / 0309132519879492$

research (Crampton, 2011; Crampton and Elden, 2006). Governmentality has provided the analytical framework for much of this geographical work on calculable territory (Hannah, 2009; Huxley, 2006; Legg, 2006; Rose-Redwood, 2006, 2012; Sevilla-Buitrago, 2012).

Certainly, this line of scholarship has significantly enhanced territorial theorization by revealing the ongoing and processual character of territorialization as a strategic and calculative practice, shifting attention away from peripheral borders while providing a timely rebuttal to the globalist narrative of state decline (Elden, 2005; Schindler, 2015). Sack's foundational theory put territory on the geographical agenda, prompting subsequent scholars to approach territory relationally as a dynamic process and reveal not its shape and extent but how it functions technologically as part of broader political strategies. However, this perspective of territory as bounded, calculable and controllable space is nevertheless limited by its overtly geometric and instrumentalist interpretation of spatial arrangements (Murphy, 2012), which for the most part is analytically blind to the extra-strategic, unintentional and material qualities of territory. As Brighenti (2010: 66) has commented, 'territoriality can be turned on and off' in the Sackian sense, lacking ontological status outside of human actions and objectives.

Notably, a physical category is lacking in Elden's (2010a) sophisticated analysis of territory's multiple registers, which includes the economic, strategic, legal and technical. Elden's (2013a: 328) meticulous historical study of territory is concerned with its existence as a 'word, concept, and practice' rather than a dynamic and changing physical entity. In fact, as Branch (2017: 137) contends, drawing on Elden's genealogical study, it is mapping and measuring technologies that 'make territory real', brought into existence through relationships between ideas, practices and techniques. Whereas the dialectical perspective has tended to conceive territory as a secondary effect of capitalist relations, strategic interpretations inspired by Foucault have considered territory to be ancillary to processes of calculation, framed as an invention of cartography made possible in the sixteenth century through new grid-based mapmaking techniques and the 'geometricization of space' (Branch, 2014: 99).

\section{Rhizomatic}

To use the idiosyncratic terminology of Deleuze and Guattari (1994), the impact of their 'geophilosophy' on territorial theorization has been peculiarly schizophrenic: under their sway, territory has been conceived as simultaneously transitory and elemental. Deleuze and Guattari have been instrumental in popularizing what has been termed a 'flat ontology', 
To cite this article: Usher, M. (2019) Territory incognita. Progress in Human Geography, DOI: $10.1177 / 0309132519879492$

which has radically upended the hierarchical, 'nested' understanding of scale in human geography, with far-reaching implications for the concept of territory (Marston et al., 2005; Routledge, 2015). Whereas scalists' dialectical interpretation of territory splintered the spatio-legal schema into differentiated bounded spaces along a vertical axis, the flat rhizomatic ontology advocated by Deleuze and Guattari has metaphorically passed it through a mincer. The resulting product is a whorled and pleated 'territorial assemblage...a fuzzy aggregate' (Deleuze and Guattari, 2004: 382), precariously constituted from the knotting, congealing and holding together of elongated stands of organic and inorganic matter, emerging immanently like rhizomes into undetermined spatial formations that are at once singular, material and provisional. This is a view of territory from the inside looking 'out', as opposed to the traditional perspective from the outside looking 'down'; territory from 'the middle....intermezzo' (Ibid: 26).

Deleuze and Guattari (1994: 86) formulated their geophilosophy in direct opposition to theoretical concepts that seek universal application through abstraction. In contrast, Deleuze and Guattari sought to embed philosophical speculation in an 'earthly materialism' (Saldanha, 2017: 11), hence subjectivity, power and emancipation are described in a rich spatial language that is usually reserved for geographical research. Their materialist analysis, liberally strewn with ecological and geological terms, reminiscent of Ratzel in fact, is instead directed towards the physis, the physical environment constituted of soil, energy, rock, vegetation, meteorology and animals (Grosz, 2008). Gasché (2014) has gone as far as to suggest that 'geocentrism', an abiding concern with earthly matter and process, has been the guiding element of Deleuze and Guattari's philosophical work, which for them provides the immediate context for social and political life (see Clark, 2017; Yusoff, 2017). Indeed, the rhizome was identified by Deleuze and Guattari as a central descriptor for their 'naturalist ontology' (Protevi, 2013) due to its having indicative spatial and ecological attributes.

In terms of its spatial morphology, the rhizome, which is non-hierarchical and horizontally nomadic, cannot be incorporated into the centralized logos of 'state philosophy' based on visual representation and geometric order. The orthodox understanding of territory as a bounded administrative space, still entrenched in mainstream political theory (Häkli, 2001), is the exemplar and foremost guarantor of what Deleuze and Guattari (2004: 15) describe as the 'arborescent' model. This model has a branch-like structuration characterized by a linear chronology of bifurcating development from an original seed to resultant canopy, founded on a binary logic emanating from an original single point. It is a vertical spatial 
To cite this article: Usher, M. (2019) Territory incognita. Progress in Human Geography, DOI: $10.1177 / 0309132519879492$

system dictated by hierarchy and based around a dominant centre (the trunk) and foundation (root system). The rhizomatic model is by contrast 'acentred' without a discernible beginning or end, where all points are connected in a networked system that develops in multiple directions and is not governed by a unifying logic: 'The rhizome operates by variation, expansion, conquest, capture, offshoots....without a general and without an organizing memory or central automaton' (Ibid: 22).

Conceiving space rhizomatically, as a sprawling, immanently developing assemblage without a designated centre or 'general', has transformed the conceptualization of space within social and political theory (Dewsbury, 2011; Dittmer, 2017). For the concept of territory, conventionally premised on the assumption of a central automaton presiding over a homogenous space, the challenge of assemblage thinking could be existential. This networked conceptualization of territory has begun to gain purchase in mainstream theorization, particularly through the work of Hardt and Negri (2001), who have realized for rhizomatic analysis what Brenner achieved for the dialectical model. Through the distorted prism of Deleuze and Guattari's Capitalism and Schizophrenia, Hardt and Negri identify the emergence of a new 'rhizomatic' (41) paradigm of 'imperial sovereignty', characterized by a global legal regime enshrined in supranational institutions and materially realized by the logistical expansion of capitalist production. Territorial boundaries have been rendered obsolete by this flexible, decentralized form of sovereignty that is articulated horizontally across formerly national jurisdictions, forming one singular juridical entity. Technological and infrastructural networks extend transversally across the earth resulting in a 'smooth world' of deterritorialized flows they term 'Empire' (332), challenging the conventional understanding of the territorial state. However, much like the dialectical and strategic perspectives, the spatial attributes of the rhizome have been privileged over its earthly materiality. As Hardt and Negri (2001: 190) surmise, '[i]n this smooth space of Empire, there is no place of power...Empire is an ou-topia, or really a non-place'.

This privileging of spatiality over materiality can be detected in the application of Deleuze and Guattari's philosophy to urban studies and in the wider assemblage debate. Smith (2003: 565), a notable proponent of Deleuzian philosophy, has stated that 'territories vanish through deterritorialization as the world is conceptualized as a living dermis with an infinite bundle of (un)folds and surfaces'. Similarly, Amin (2002: 389) proposes that 'we might begin to think of places in nonterritorial terms, as nodes in relational settings, and as a site of situated practices'. From within political geography, Painter (2010: 1116) describes territory as a 'non-material product of networked socio-technical practices', which 'should be 
To cite this article: Usher, M. (2019) Territory incognita. Progress in Human Geography, DOI: $10.1177 / 0309132519879492$

examined not as an actual state space, but as the powerful, metaphysical effect of practices that make such spaces appear to exist'. Claude Raffestin is one of the foremost thinkers of territory in human geography, and strongly influenced by Deleuze and Guattari, arrives at the same conclusion. For Raffestin (2012), the physical environment ('exteriority') is now deeply, if not completely, mediated by the social environment ('alterity'), particularly through the signifying system of language, information and digital simulation, 'stripped of its geographicity' (Klauser, 2012: 116). This prompts Raffestin (2012: 131) to propose that '[w]e now "write" territory like a text. Territory is no longer a cause, but is "caused"'.

\section{Reclaiming nomos}

This is the ultimate irony of Agnew's territorial trap: tracing the lineage of territorial theorization back through its various permutations leads to a vertiginous analytical void where territory was assumed to reside. Where the 'physical substratum' of territory has been acknowledged (Shah, 2012: 58), it appears largely in the service of the state, naturalizing its existence. The resulting impression is of a nation-state floating 'in the air' above its territory, with the latter either rendered abstract or vanquished altogether as a material reality. And certainly, the 'ideational' conceptualization continues to prevail as the dominant analytical lens in the humanities and social sciences, which conceives territory as principally 'a political, social, and cultural construct' (Atzili and Kadercan, 2017: 124). Even today in an era of rapid environmental change and ecological consciousness, the 'physical components' are acknowledged to be 'a core feature of territory, [but] they are fairly straightforward' (Ibid: 121). This lack of concern with the material attributes of territorial space is reflective of a longstanding tendency rooted in the binary divide between the juridical and physical. The pioneering scholarship of Gottmann, Sack, Raffestin and Elden has pushed theorization of territory well beyond its narrow legalistic conceptualization, and their significant, multifaceted contributions have been necessarily abridged here. Similarly, irrespective of their profound impact on subsequent work, Lefebvre, Foucault, Deleuze and Guattari did not identify as theorists of territory, and their writing on the subject was just one aspect of a manifold spatial philosophy. Nevertheless, from Bartolus through to Weber, those trained in jurisdiction have dominated the conceptual development of territory, privileging idealist norms over physical geography, naturalizing the state and territory linkage.

As Deleuze contends, this dominant form of state philosophy 'effectively functions in the mind', as a simplified geometric representation of the totalizing vision of the sovereign, which 'conforms to the goals of the real State' (Deleuze and Parnet, 2002: 13). Cartesian territory is violently expunged of its material content, allowing sovereign power to glide 
To cite this article: Usher, M. (2019) Territory incognita. Progress in Human Geography, DOI: $10.1177 / 0309132519879492$

unimpeded and pervasively across a hypothetical flat surface. Here, territory and sovereignty are functionally commensurate, fastened together through a juridical glue, mutually affirming of each other's veracity. However, since the 1970s, relational philosophy has progressively splintered, fragmented and minced the Westphalian bordered territory, revealing the contingency of territory, unclasping it from legal sovereignty. While these successive waves of relational theorization have provided a more sophisticated conceptualization to that of a legal container, territory as a material reality remains strangely ancillary and elusive, conceived as secondary to law, capitalism, strategy and networks. As Delaney (2005: 9) recognizes, 'territory is commonly understood as a device for simplifying and clarifying something else...[i]n order to have this effect territory itself has to be taken as a relatively simple and clear phenomenon'. However, this simplified representation of territory is becoming increasingly difficult to uphold as planetary feedback loops are activated and ecological crises proliferate. Indeed, the Anthropocene has birthed 'a new mode of thought' (Moore, 2016: 2) as increasingly animated earth systems oblige theorists to apprehend the material agency and politicized nature of the planet (Castree 2014a, 2014b; Clark, 2013; Dalby, 2007; Yusoff, 2016). According to Latour (2017: 275), this reassertion of the physical world has led to a 'crisis of representation' in traditional rationalist political theory, challenging the two-dimensional Westphalian model of bordered territorial sovereignty: the 'fantasy of empty, smooth space...has collapsed, and place has emerged in its truly monstrous uncanny dimension, which is to say its nonhuman dimension' (Morton, 2016: 10).

Territory, long regarded as abstract and inert, has sprung alive again as a three-dimensional, dynamic physical entity not subordinated under sovereign control, 'as something on which an entity depends for its subsistence' (Latour, 2017: 263). The planetary crisis has prompted a revaluation of humans' biophysical reliance on territory, as a substrate that roots and nourishes its population, which is being destabilized by global environmental change. To emphasize the environmental foundations that root nation-states in the earth, Latour (2018: 87) advocates a shift in analytical focus from spatiality to materialism, territory to the 'terrestrial', inadvertently invoking political geography's abandoned more-than-human beginnings. Understandably, Latour cautions against engagement with Lebensraum but then draws upon the Nazi sympathizing Carl Schmitt's reworking of nomos to rematerialize territory. For Schmitt, law, and the modern conceptualization of territorial sovereignty, has become decoupled from the earth in modern political theory, belying its origins in the measurement, division and appropriation of the land. Inspired by Ratzel and Mackinder, 
To cite this article: Usher, M. (2019) Territory incognita. Progress in Human Geography, DOI: $10.1177 / 0309132519879492$

Schmitt (2003: 42) insisted that nomos has a broader meaning than written law as commonly assumed, being physically inscribed in the land, 'bound to the earth and related to the earth'. Nomos is the 'prelude to territoriality' (Dean, 2006: 5), an elemental, territorializing force field that binds, via law, a people to their land, politically and spiritually. The earth is the matrix of law and nomos unites them as land is appropriated, distributed and cultivated, where, similar to Ratzel, territory is not imposed upon the earth but emerges physically from it. And like Ratzel, Schmitt is enjoying a renaissance in political geography (Legg, 2011; Minca, 2006; Minca and Rowan, 2016).

However, notwithstanding the theoretical limitations of Schmitt's understanding of territory or his intimate links with Nazism (Elden, 2010b), the legal theorist is considered a modernday Hobbes operating in the interests of total sovereignty, the realist par excellence, aggrandizing and glorifying the nation-state. Rather than turning to Schmitt, or indeed Ratzel, for a materialist ontology of territory, we can instead draw on Deleuze and Guattari's alternative reading of nomos, rematerializing their geophilosophy in the process. Of all postwar theorization of territory, it is Deleuze and Guattari that have provided the most sustained engagement with the nomos and physis relationship. However, crucially, their interpretation of nomos is directed against sovereignty, drawing on inspiration from the natural world, as Ratzel had, but for emancipation from the state's centripetal, universalizing force. In their naturalist ontology, the nomos is a nonmetric, volatile and unassimilable form of space; smooth rather than striated, haptic as opposed to optic, 'desert, steppe, ice, and sea' (Deleuze and Guattari, 2004: 573). For Deleuze and Guattari, nomos is formative of territory but not exhausted by it, being an unpredictable elemental force at the threshold of the state. Territory as a rhizomatic landscape is akin to 'Swiss cheese' (Ibid: 482), 'with its gaps, detours, subterranean passages, stems, openings, traits, holes, etc.' (484), containing myriad possibilities for evasion from state oversight. Where Schmitt (2003: 75) describes nomos as a 'fence-word' that isolates, grounds and protects the population, for Deleuze and Guattari it is a vector of deterritorialization that cannot be partitioned: 'It is a very special kind of distribution...a space without borders or enclosure...it stands in opposition to the law or the polis, as the backcountry, a mountainside, or the vague expanse around a city' (Deleuze and Guattari, 2004: 443).

A way out of the territorial trap that the Westphalian model sprung is to bring physical and political geography closer together, as Mackinder, Ratzel and Semple originally urged before their agenda became toxified by imperialism, focusing on territory itself, its more-thanhuman elements. This would depart from 'political geometry', which O'Loughlin (2018: 147) 
To cite this article: Usher, M. (2019) Territory incognita. Progress in Human Geography, DOI: $10.1177 / 0309132519879492$

claims has privileged "space" to the detriment of "place" in understanding the geography of politics', overlooking the complexity, particularity and dynamism of the earth's material features. Indeed, the trap of methodological territorialism should not imply moving 'beyond territory' (Allen, 2016) but should prompt a more focused examination of its properties and particularities (Uitermark, 2015); how states of matter inflect, deflect or expedite matters of state through their unique and dynamic environmental properties. Physical geography offers both facilities and resistance to political strategy, requiring inductive, empirically detailed studies of the different environmental settings in which territorialization occurs, focused on the qualitative as well as quantitative aspects- the terroir of territory. The recent environmental turn in political geography indicates a shift in this direction (Depledge, 2015; Grundy-Warr et al., 2015; Benjaminsen et al., 2017), as does the gradual shedding of political ecology's 'traditional ambivalence' towards state and territory (Robbins, 2008; Parenti, 2016; Robertson, 2015: 458; Whitehead et al, 2007).

\section{Territory intermezzo}

Following Deleuze and Guattari, this could involve approaching the study of territory from the 'middle' rather than 'above', intermezzo, as at once machinic, nomadic and affective. For Deleuze and Guattari (2004: 330), territorial assemblages are a 'veritable machinic opera' comprised of motley elements, organic and inorganic, human and inhuman, which provide spatial expression through temporary synthesis, 'tying together orders, species, and heterogeneous qualities'. Territory cannot exist outside of these rhizomatic connections, which contracts and expands with their shortening and lengthening, while being dependent on nonhuman elements that are not readily submitted to human strategic intention. In Deleuze and Guattari's (2004: 468) geophilosophy, therefore, the state is first and foremost an 'apparatus of capture' that consolidates through a capacity to territorialize flows of energy and matter into stabilized assemblages, emerging from its relation with the earth (Banister, 2014). Here, territory is not a fixed space of exclusive sovereign authority but an 'engineering project' (Mitchell, 2011: 3), cultivated, integrated and expanded physically via infrastructure, technological systems and institutional arrangements, to establish what Ratzel termed a 'grasp on the soil'.

Mukerji's (2009) notion of 'territorial engineering', which she develops through a study of the Canal du Midi in France, draws attention to the logistical power involved in territorialization, exercised not only through violence but earthworks as well. The importance of engineering in the physical cultivation of territorial space, or 'techno-territoriality' (Carroll, 2006), has been demonstrated in other studies, including energy development in England, 
To cite this article: Usher, M. (2019) Territory incognita. Progress in Human Geography, DOI: $10.1177 / 0309132519879492$

Georgia and European Union (Barry, 2013; Bouzarovski et al, 2015; Mitchell, 2011); the construction of roads, rail, rivers and canals in Panama, Peru, Britain and France (Carse, 2014; Harvey and Knox, 2015; Jones and Merriman, 2012; Joyce, 2013; Pritchard, 2011); and water management in California, Egypt, Spain, Singapore and Pakistan (Akhter, 2015; Carroll, 2012; Mitchell, 2002; Swyngedouw, 2015; Usher, 2018). As Ratzel (1898a: 450) surmised, 'great rulers...have been always builders of highways, canals, and bridges', while Semple (1911: 209) exalted the 'hand-made territory' of the Dutch. Emerging research on geopolitical ecology is also drawing attention to the machinic quality of territory, which is extended into broader international configurations via transboundary resource management arrangements (Bigger and Neimark, 2017; Sneddon, 2015; Usher, 2019).

Similarly, scholarship on the 'socioenvironmental state' (Nightingale, 2018: 689) foregrounds its rootedness in the earth, which examines how resource and land management provides a material basis for territorial formation and restructuring (Asher and Ojeda 2009; Peloquin, 2013). Pushing this agenda forward, however, Peters et al (2018: 9) recognize that 'territory leverages the multiplicity of nature', including that of land but also seas, oceans, underground and atmosphere, and environments in between- mudflats, floodplains, coasts, mineshafts and glaciers. More recent work has begun to explore this machinic multiplicity, paying greater attention to the manifold agencies, materialities and forces of nature that undergird territorial space and augment sovereign power, including landforms (Weizman, 2007), airspace (Adey, 2010a), sea ice (Steinberg and Kristoffersen, 2017), geological formations (Squire, 2016) and oceans (Satizábal and Batterbury, 2018; Wirth, 2016). Approaching territory as an engineered machinic assemblage rather than a priori abstract container demands heightened analytical sensitivity to its heterogeneous consistency, its 'elemental ontology' of 'rock, earth, water, air and fire' (Squire, 2016: 546).

There is growing interest in the nomadic qualities of territorial space, which is constantly obscuring, impeding and evading sovereign rule. While these diverse elemental contexts are subject to territorialization processes, they do not acquiesce willingly, being constituted of dimensions, textures and intensities that cannot be wholly comprehended or controlled by a central authority. Scholarship on the vertical, and increasingly, volumetric dimensions of territory has stretched analysis to the heights and depths of territorial space, from the atmosphere to the subterranean (Braun, 2000; Elden, 2013b; Squire and Dodds, 2019; Williams, 2013). As Graham (2016: 3) contends, theorization of territory has been undermined by '"flat" geographic thinking', neglecting, and more seriously, obscuring the vertical dimension of power through which sovereignty is increasingly exercised, 'above, 
To cite this article: Usher, M. (2019) Territory incognita. Progress in Human Geography, DOI: $10.1177 / 0309132519879492$

below and around borders' (see also Billé, 2019). However, crucially, while Bridge (2013: 55) has suggested a '3D' interpretation of territory 'magnifies the possibilities of relative location, affording additional means of control', this latent endowment entails more complex logistical, technical and strategic challenges. As Lehman (2013: 52) observes, '[v]olumes are irreducible to and in excess of the apparatuses of their capture'; the challenge of distance is exacerbated by that of mass, density, viscosity and immersion.

This can be witnessed at ground level with recent studies into the volatile, intractable 'morethan-human landscape' of terrain, which 'may impede or disrupt a state's vision, navigation, or administrative practice' (Boyce, 2016: 246). Focusing on mountain warfare in the Korengal Valley, Afghanistan, Gordillo (2018: 55) argues that terrain has been understudied as a textured, volumetric entity that exceeds territorial appropriation, often being 'intrinsically opaque' to combatants and curtailing movement and vision in unequal ways: 'Terrain was for [Americans] a hostile and restricting materiality whereas for insurgents it was the opposite'. Gregory (2016: 5) draws on the experiences of soldiers fighting in the World Wars and Vietnam to illustrate how different materialities of 'trickster nature'- mud, desert and rainforest- impact on conflicts in unforeseen ways, revealing the limits of state strategy. Clark and Jones (2017: 124) also highlight the 'push-back of territory's materialities' in their study of state formation in Iceland, where the 'unruliness' of its environmentfrequent mudslides, eruptions and earthquakes- has defined its modern political identity. In Barry's (2013: 1) study of the Baku-Tbilisi-Ceyhan oil pipeline, the physical geography of Georgia is revealed to possess an 'unpredictable and lively' capacity to animate geopolitics in the region, long overlooked by Western analysts.

As Elden (2017: 223) affirms, 'terrain is where the geopolitical and geophysical meet'. However, the nomadic tendencies of the physical world are not limited to land surface terrain. Adey (2010b: 6) has highlighted the immense challenges associated with governing aerial territory given the vast dimensions involved, the physical characteristics including air currents and temperature changes, and the high speed of 'aeromobilities'. Based on his historical analysis of air pollution in Britain, Whitehead (2009: 2) considers 'air government' to be essential to territorial security but describes it as an impossible task, attempting to assert order on an unorderable entity. Also challenging the terrestrial bias in political geography, Steinberg and Peters (2015) propose a research agenda that examines how the volumetric depth, roiling matter and colossal forces of marine environments are accommodated into or resist territorial arrangements. Campling and Colás (2018: 777) reveal the inherent difficulties of securing 'terraqueous territoriality' in this geophysical 
To cite this article: Usher, M. (2019) Territory incognita. Progress in Human Geography, DOI: $10.1177 / 0309132519879492$

context, especially for lesser developed countries, which they explore in respect to exclusive economic zones (EEZs) and counter-piracy initiatives (see also Mason and Khawlie, 2016). Sammler (2019: 2) argues that rising sea levels are pushing back legal 'baselines', the coastline borders of nation-states, blurring physically and theoretically the very notion of bounded sovereignty.

Descending underground, what has been called the 'geological turn' (Dalby, 2013: 57) and 'subterranean turn' (Squire and Dodds, 2019) in political theory is also challenging orthodox thinking on territory. As Clark and Yusoff (2017: 15) propose, this has occasioned the 'politicization of the geologic' and a 'geologization of the political', giving rise to the new field of 'political geology' (Bobbette and Donovan, 2019). The geophilosophy of Deleuze and Guattari has been integral, informing Grosz's (2017: 135) thought on geopower, or the impersonal 'forces of the earth' that are necessary for and precede political orderings such as territory, while also threatening these arrangements: 'forces we summon up rather than control'. For Clark (2017: 2015), the original 'territorial impulse' was prompted by humans adapting to shifting alluvium and floodplain dynamics, and 'is inextricable from physical processes that are fundamental to the vertical layering of the planet's crust...territory emerges dripping from the watery dynamics of sedimentary geology'. However, this origin story of territory has been forgotten along with the disruptive, more-than-human capacities of the subterranean realm, where more immediate and practicable concern with borders has taken priority.

This overlooks the dependence of states on the subterranean, as Melo Zurita and Monroe (2019: 40) demonstrate in their study of the 'uncooperative volume' of the Yucatan Peninsula, Mexico, where the horizontal spread of the Spanish was checked by their lack of vertical access to aquifers. Gormally et al (2018: 73) also conceive territory as a 'geosocial challenge' rather than simple extent, in respect to the required administrative capacity for implementing underground carbon storage (see also Slesinger 2018; Valdivia, 2015). While there has been increasing interest in the geological power of humans signalled by the Anthropocene, it is the 'radical indifference of geology to human life' (Yusoff, 2017: 107), its 'utter matter' (Macfarlane, 2019: 4) and unfathomable otherness, which is more salient and perturbing, revealing the 'limits to our ability to 'govern' the rhythms and singularities of earth systems' (Clark, 2017: 229). The Anthropocene has upended the preoccupation with surface in modern political thought, revealing territory to be, as Ratzel proposed, a 'product of forces greater than those of human will', prompting a rethinking of sovereignty itself (Mann and Wainwright, 2018). 
To cite this article: Usher, M. (2019) Territory incognita. Progress in Human Geography, DOI: $10.1177 / 0309132519879492$

Finally, there is an emerging research agenda focused on the affective qualities of territory, which takes seriously the capacity of 'volumetric environments' to incite emotional response in an everyday embodied register (Fregonese, 2017: 9). Inspired by Deleuze and Guattari in particular, there is growing interest in the relations between nation-states, materiality and affect (Closs Stephens, 2016; Woodward, 2014), although less attention has been afforded to explicitly 'territorialized affective ties' (Merriman and Jones: 2017: 604). This concerns the tangible thereness of territory as a 'tactile' or 'haptic' space (Deleuze and Guattari, 2004), which is reinterpreted as an active force impressing upon human bodies, hampering or facilitating their movement, altering their moods. As Gordillo (2018: 55) contends, the rugged, mountainous territory of Afghanistan had 'affective power' over combatants, instilling a profound despondency in the American troops. Similarly, Gregory (2016) distinguishes between cartography and 'corpography', where the latter refers in his example to the adverse embodied reaction of soldiers faced with the fatal monotony of mud.

The physical characteristics of territory also elicit responses that are formative of citizenship, allowing for the manipulation of emotional registers in the interests of political strategy. Militz and Schurr (2016) explore 'affective nationalism' in Azerbaijan, where belonging is cultivated in the population through bodily encounters with their surroundings. Matless (2016: 32) speaks of 'landscaped citizenship' that emerges through interaction with scenic natural settings, such as the idealized countryside in England. Patriotic and rugged values and norms are cultivated through activities such as walking and rock climbing in these landscapes, particularly in the 'affective ecologies' of national parks (Crang and Tolia-Kelly, 2010: 2326). This is what Semple called the 'integrating force' of territory, following Ratzel (1898b: 373-4) who observed 'great states call forth stirring emotions, peculiarly their own, which keep our feelings alive and ourselves busied'. For Adey (2010b: 21), the immersive immensity of the atmosphere produces agile fighter pilots as 'aerial subjects', cultivated 'through the aeroplane's relation with the nation, state and territoriality'. Benwell (2017: 17) argues that extracted earth from the Falklands/Malvinas reinforced 'affective connections to national territory' through public exhibitions, activating an 'elemental nationalism'. Whether focused on, below or above ground, this research on affective territory can, as some scholars have urged (Elden, 2013b; Grove, 2019; Klinke, 2018), provide a basis for integrating biopolitics and geopolitics: 'the corporeal is a crucial aspect of territory' (Elden, 2018: 217). As Ratzel (2018 [1901]: 69) insisted, presciently, fatefully, territory is not only a legal space but a dynamic 'system', an 'intensity of habitation', a living space. 
To cite this article: Usher, M. (2019) Territory incognita. Progress in Human Geography, DOI: $10.1177 / 0309132519879492$

Taken together, an emerging fifth wave of theorization is overturning a century of thinking on territory, which is rooted precariously yet necessarily in the physical world. Deleuze and Guattari's writings, habitually overlooked as faddish and apolitical (Sibertin-Blanc, 2016), is providing inspiration for this wave, although Marx and Foucault still dominate proceedings in political ecology (see Harris, 2017; Loftus 2018). The crisis of representation has provided an opportune moment to return to political geography's more-than-human beginnings and 'silenced' canon (Keighren et al., 2012), but with the reverse intention of challenging rather than reinforcing state philosophy, reclaiming nomos from its realist, masculine heritage. Indeed, the field of new materialism, with close links to feminism, has been instrumental in rooting Deleuze and Guattari's geophilosophy back in ecology (Bennett, 2010; Coole and Frost, 2010; Grosz, 2008). As well as taking territorial theorization beneath 'surface geographies' (Tolia-Kelly, 2013: 154), new materialism can also queer a field long the intellectual terrain of white European males (Halvorsen, 2018). While new materialism has been subject to criticism for its depoliticizing tendencies (Swyngedouw and Ernstson, 2018), somewhat unfairly given its links to feminist thought, it can ground theorization that has long neglected the earth's material forces while opening up analysis to divergent voices (Secor, 2018). As Semple (1911: 205) maintained, who pursued both of these ends, '[f]or convenience' sake, we adopt the abstraction of a boundary line; but the reality behind this abstraction is the important thing'- the more-than-legal, more-than-strategic, more-thanhuman world.

Adey P (2010a) Vertical security in the megacity: Legibility, mobility and aerial politics. Theory, Culture \& Society 27(6): 51-67

Adey P (2010b) Ariel Life. Oxford: Wiley-Blackwell

Agamben G (1998) Homo sacer: Sovereign power and bare life. Stanford, CA: Stanford University Press.

Agnew J (1994) The territorial trap: The geographical assumptions of international relations theory. Review of International Political Economy 1(1): 53-80.

Agnew J (2005) Sovereignty regimes: Territoriality and state authority in contemporary world politics. Annals of the Association of American Geographers 95(2): 437-461.

Agnew J (2010) Still Trapped in Territory? Geopolitics 15(4): 779-784. 
To cite this article: Usher, M. (2019) Territory incognita. Progress in Human Geography, DOI: $10.1177 / 0309132519879492$

Akhter M (2015) Infrastructure nation: State space, hegemony, and hydraulic regionalism in Pakistan. Antipode 47(4): 849-870.

Allen J (2011) Powerful assemblages? Area 43(2): 154-157.

Allen J (2016) Topologies of power: Beyond territory and networks. London: Routledge.

Allen J and Cochrane A (2010) Assemblages of State Power: Topological Shifts in the Organization of Government and Politics. Antipode 42(5): 1071-1089.

Amin A (2002) Spatialities of globalization. Environment and Planning A: Economy and Space 34(3): 385-399.

Anderson M (1996) Frontiers: Territory and state formation in the modern world. Cambridge: Polity Press.

Anderson P (1979) Lineages of the absolutist state. London: Verso.

Anonymous (1899) Ratzel's 'Political Geography'. The Geographical Journal 13 (2): 171-173.

Antonsich M (2009) On territory, the nation-state and the crisis of the hyphen. Progress in Human Geography 33(6): 789-806.

Appadurai A (1996) Sovereignty without territoriality: Notes for a postnational geography. In: Arbor A (ed.), The geography of identity, Michigan, MI: The University of Michigan Press, 40-58.

Asher K and Ojeda D (2009) Producing nature and making the state: Ordenamiento territorial in the Pacific lowlands of Colombia. Geoforum 40: 292-302.

Ashworth L M (2010) Realism and the spirit of1919: Halford Mackinder, geopolitics and the reality of the League of Nations. European Journal of International Relations 17(2): 279-301.

Atzili B and Kadercan B (2017) Territorial designs and international politics: The diverging constitution of space and boundaries. Territory, Politics, Governance 5(2): 115-130.

Banister J (2014) Are you Wittfogel or against him? Geophilosophy, hydro-sociality, and the state. Geoforum 57: 205-214.

Barua M (2018) Ratzel's biogeography: a more-than-human encounter. Journal of Historical Geography 61:102-108. 
To cite this article: Usher, M. (2019) Territory incognita. Progress in Human Geography, DOI: $10.1177 / 0309132519879492$

Barry A (2013) Material politics: Disputes along the pipeline. Oxford: Wiley-Blackwell.

Bassin M (1987) Imperialism and the nation state in Friedrich Ratzel's political geography. Progress in Human Geography 11(4): 473-495.

Bassin M (1997) History and philosophy of geography. Progress in Human Geography 21(4): 563-572.

Bassin M (2003) Between realism and the 'New Right': Geopolitics in Germany in the 1990s. Transactions of the Institute of British Geographers, 28(3): 350-366.

Bauman Z (2003) Utopia with no Topos. History of the Human Sciences 16(1): 11-25.

Benjaminsen T A, Buhaug H, McConnell F, Sharp J and Steinberg P (2017) Political Geography and the environment. Political Geography 56: A1-A2.

Bennett J (2010) Vibrant matter: A political ecology of things. Durham, NC: Duke University Press.

Bennett T and Joyce P (2010) Material powers. London: Routledge.

Benwell M (2017) Going underground: Banal nationalism and subterranean elements in Argentina's Falklands/Malvinas claim. Geopolitics doi.org/10.1080/14650045.2017.1387776

Bigger P and Neimark B D (2017) Weaponizing nature: The geopolitical ecology of the US Navy's biofuel program. Political Geography 60: 13-22.

Billé F (2019) Introduction: volumetric sovereignty. Environment and Planning D: Society and Space. Available at: http://societyandspace.org/2019/04/10/volumetric sovereigntyforum/ (accessed 24 September 2019)

Bobbette A and Donovan A, eds (2019) Political geology: Active stratigraphies and the making of life. London: Palgrave Macmillan.

Bourdieu P (2014) On the state: Lectures at the Collège de France 1989-1992. Cambridge: Polity Press.

Bouzarovski S, Bradshaw M and Wochnik A (2015) Making territory through infrastructure: The governance of natural gas transit in Europe. Geoforum 64: 217-228.

Boyce G (2016) The rugged border: Surveillance, policing and the dynamic materiality of the US/Mexico border. Environment and Planning D: Society and Space 34(2): 245-262. 
To cite this article: Usher, M. (2019) Territory incognita. Progress in Human Geography, DOI: $10.1177 / 0309132519879492$

Branch J (2014) The cartographic state: Maps, territory and the origins of sovereignty. Cambridge: Cambridge University Press.

Branch J (2017) Territory as an institution: Spatial ideas, practices and technologies. Territory, Politics, Governance 5(2): 131-144.

Braun B (2000) Producing vertical territory: Geology and governmentality in late Victorian Canada. Cultural Geographies 7(1): 7-46.

Braun B and Whatmore S (2010) Political matter: Technoscience, democracy and public life. Minneapolis, MN: University of Minnesota.

Brenner N (2004) New state spaces: Urban restructuring and state rescaling in Western Europe. Oxford: Oxford University Press.

Brenner N, Jessop B, Jones M and MacLeod G (2003) State/space: A reader. Oxford: Blackwell.

Brett A (2011) Changes of state: Nature and the limits of the city in early modern natural law. Princeton, NJ: Princeton University Press.

Bridge G (2013) Territory, now in 3D! Political Geography 34:55-57.

Brighenti AM (2010) On Territorology: Towards a General Science of Territory. Theory, Culture \& Society 27(1): 52-72.

Brown W (2010) Walled states, waning sovereignty. Brooklyn, NY: Zone Books.

Campling L and Colás A (2018) Capitalism and the sea: Sovereignty, territory and appropriation in the global ocean. Environment and Planning D: Society and Space 36(4): 776-794.

Caporaso J A (1996) The European Union and Forms of State: Westphalian, Regulatory or Post-Modern? JCMS: Journal of Common Market Studies 34(1): 29-52.

Carroll P (2006) Science, culture, and modern state formation. Berkeley, CA: University of California Press.

Carroll P (2012) Water and technoscientific state formation in California. Social Studies of Science 42(4): 489-516. 
To cite this article: Usher, M. (2019) Territory incognita. Progress in Human Geography, DOI: $10.1177 / 0309132519879492$

Carse A (2014) Beyond the big ditch: Politics, ecology, and infrastructure at the Panama Canal. Cambridge, MA: MIT Press.

Castree N (2014a) The anthropocene and geography II: current contributions Geography Compass 8: 450-463.

Castree N (2014b) The anthropocene and geography III: future directions Geography Compass 8: $464-476$

Charnock G (2010) Challenging New State Spatialities: The Open Marxism of Henri Lefebvre. Antipode 42(5): 1279-1303.

Chisholm G (1912) Miss Semple on the Influences of Geographical Environment. The Geographical Journa/39(1):31-37

Clark J and Jones A (2017) (Dis-)ordering the state: Territory in Icelandic statecraft. Transactions of the Institute of British Geographers 42: 123-138.

Clark N (2013) Geoengineering and geologic politics. Environment and Planning A: Economy and Space 45(12): 2825-2832.

Clark N (2017) Politics of strata. Theory, Culture \& Society 34(2-3): 211-231.

Clark N and Yusoff K (2017) Geosocial formations and the Anthropocene. Theory, Culture \& Society 34(2-3): 3-23.

Claval P (2006) The scale of political geography: An historical introduction. Tijdschrift voor Economische en Sociale Geografie 97(3): 209-221.

Closs Stephens A (2016) The affective atmospheres of nationalism. Cultural Geographies 23(2): 181-198.

Coole D and Frost S (2010) New materialisms: Ontology, agency and politics. Durham, NC: Duke University Press.

Cowen D and Smith N (2009) After geopolitics? From the geopolitical social to geoeconomics. Antipode 41: 22-48.

Cox K R (1991) Redefining 'territory'. Political Geography Quarterly 10(1): 5-7.

Cox K R (2003) Political geography and the territorial. Political Geography 22(6): 607-610. 
To cite this article: Usher, M. (2019) Territory incognita. Progress in Human Geography, DOI: $10.1177 / 0309132519879492$

Crang M and Tolia-Kelly D (2010) Nation, race, and affect: Senses and sensibilities at national heritage sites. Environment and Planning A: Economy and Space 42: 2315-2331.

Crampton J W (2011) Cartographic calculations of territory. Progress in Human Geography 35(1): 92-103.

Crampton J W and Elden S (2006) Space, politics, calculation: an introduction. Social \& Cultural Geography 7(5): 681-685.

Croxton D (1999) The Peace of Westphalia of 1648 and the Origins of Sovereignty. The International History Review 21(3): 569-591.

Dalby S (2007) Anthropocene geopolitics: Globalisation, empire, environment and critique. Geography Compass 1(1): 103-118.

Dalby S (2013) Geopolitics in the Anthropocene: A reply to Clark, Kahn and Lehman. Political Geography 37: 56-57.

Dean M (2006) A political mythology of world order: Carl Schmitt's Nomos. Theory, Culture \& Society 23(5): 1-22.

Delaney D (2005) Territory: A short introduction. Oxford: Blackwell.

Deleuze G and Guattari F (2004 [1987]) A thousand plateaus: Capitalism and schizophrenia. Minneapolis, MN: University of Minnesota Press.

Deleuze G and Guattari F (1994) What is philosophy? New York, NY: Columbia University Press.

Deleuze G and Parnet C (2002) Dialogues II. New York, NY: Columbia University Press.

Dell'Agnese E (2013) The political challenge of relational territory. In: Featherstone D and Painter J (eds), Spatial politics: Essays for Doreen Massey, London: Wiley-Blackwell, 115124.

Depledge D (2015) Geopolitical material: Assemblages of geopower and the constitution of the geopolitical stage. Political Geography, 45: 91-92.

Dewsbury J D (2011) The Deleuze-Guattarian assemblage: Plastic habits. Area 43(2): 148153. 
To cite this article: Usher, M. (2019) Territory incognita. Progress in Human Geography, DOI: $10.1177 / 0309132519879492$

Dittmer J (2017) Diplomatic material: Affect, assemblage and foreign policy. Durham, NC: Duke University Press.

Dodds K (2000) Political geography II: some thoughts on banality, new wars and the geopolitical tradition. Progress in Human Geography 24(1): 119-129.

Elden S (2005) Missing the Point: Globalisation, Deterritorialisation and the Space of the World. Transactions of the Institute of British Geographers 30(1): 8-19.

Elden S (2006) National Socialism and the politics of calculation. Social \& Cultural Geography 7(5): 753-769.

Elden S (2007) Governmentality, calculation, territory. Environment and Planning D: Society and Space 25(3): 562-580.

Elden S (2009) Terror and territory: The spatial extent of sovereignty. Minneapolis, MN: University of Minnesota Press.

Elden S (2010a) Land, terrain, territory. Progress in Human Geography 34(6): 799-817.

Elden S (2010b) Reading Schmitt geopolitically: Nomos, territory and Großraum. Radical Philosophy 161: 18-26.

Elden S (2013a) The birth of territory. Chicago, IL: Chicago University Press.

Elden S (2013b) Secure the volume: Vertical geopolitics and the depth of power. Political Geography 34: 35-51.

Elden S (2017) Legal terrain- the political materiality of territory. London Review of International Law 5(2): 199-224.

Elden S (2018) Shakespearean territories. Chicago, IL: Chicago University Press.

Farinelli F (2000) Friedrich Ratzel and the nature of (political) geography. Political Geography 19(8): 943-955.

Flint C (2003) Dying for a "P"? Some questions facing contemporary political geography. Political Geography 22: 617-620.

Foucault M (2003) Society Must Be Defended. New York, NY: Picador.

Foucault M (2007) Security, territory, population. Basingstoke: Palgrave Macmillan. 
To cite this article: Usher, M. (2019) Territory incognita. Progress in Human Geography, DOI: $10.1177 / 0309132519879492$

Foucault M (2008) The birth of biopolitics. Basingstoke: Palgrave Macmillan.

Fregonese S (2017) Affective atmospheres, urban geopolitics and conflict (de)escalation in Beirut. Political Geography 61: 1-10.

Frenkel S (1992) Geography, empire, and environmental determinism. Geographical Review 82(2): 143-153.

Gasché R (2014) Geophilosophy: On Gilles Deleuze and Felix Guattari's What is philosophy? Chicago, IL: Northwestern University Press.

Gerhardt H, Steinberg P E, Tasch J, Fabiano S J and Shields R (2010) Contested Sovereignty in a Changing Arctic. Annals of the Association of American Geographers 100(4): 992-1002.

Giddens A (1985) The nation-state and violence. Cambridge: Polity Press.

Gordillo G (2018) Terrain as insurgent weapon: An affective geometry of warfare in the mountains of Afghanistan. Political Geography 64: 53-62.

Gormally A, Markusson N and Bentham M (2018) The pore space scramble; challenges and opportunities for subsurface governance. Geoforum 95: 70-77.

Gottmann J (1947) De la méthode d'analyse en géographie humaine'. Annales de Géographie 56: 1-12.

Gottmann J (1973) The significance of territory. Charlottesville, VA: University Press of Virginia.

Gottmann J (1975) The evolution of the concept of territory. Social Science Information 14(3): 29-47.

Graham S (2016) Vertical: The city from satellites to bunkers. London: Verso.

Gregory D (2016) The Natures of War. Antipode 48(1): 3-56.

Grosz E (2008) Chaos, territory, art: Deleuze and the framing of the earth. New York, NY: Columbia University Press.

Grosz E (2012) Geopower. Environment and Planning D: Society and Space 30: 973-975.

Grove J V (2019) Savage ecology: War and geopolitics at the end of the world. Durham, NC: Duke University Press. 
To cite this article: Usher, M. (2019) Territory incognita. Progress in Human Geography, DOI: $10.1177 / 0309132519879492$

Grundy-Warr C, Sithirith M and Li Y M (2015) Volumes, fluidity and flows: Rethinking the 'nature' of political geography. Political Geography 45: 93-95.

Häkli J (2001) In the territory of knowledge: state-centred discourses and the construction of society. Progress in Human Geography 25(3): 403-422.

Halas M (2014) Searching for the perfect footnote: Friedrich Ratzel and the others at the roots of Lebensraum, Geopolitics 19(1): 1-18.

Halverson S (2018) Decolonising territory: Dialogues with Latin American knowledges and grassroots strategies. Progress in Human Geography doi.org/10.1177/0309132518777623

Hannah M G (2009) Calculable territory and the West German census boycott movements of the 1980s. Political Geography 28(1): 66-75.

Harden C P (2012) Framing and reframing questions of human-environment interactions. Annals of the Association of American Geographers 102(4): 737-747.

Hardt M and Negri A (2001) Empire. Cambridge, MA: Harvard University Press.

Harris L M (2017) Political ecologies of the state: Recent interventions and questions going forward. Political Geography 58: 90-92.

Harvey D (1969) Explanation in geography. London: Edward Arnold.

Harvey P and Knox H (2015) Roads: An anthropology of infrastructure and expertise. Ithaca, NY: Cornell University Press.

Herz J H (1957) Rise and Demise of the Territorial State. World Politics 9(4): 473-493.

Huxley M (2006) Spatial rationalities: order, environment, evolution and government. Social \& Cultural Geography 7(5): 771-787.

Jessop B (2008) State power. Cambridge: Polity Press.

Jessop B, Brenner N and Jones M S (2008) Theorizing sociospatial relations. Environment and Planning D: Society and Space 26(3): 389-401.

Jones M (2009) Phase space: geography, relational thinking, and beyond. Progress in Human Geography 33(4): 487-506.

Jones R and Merriman P (2012) Network nation. Environment and Planning A: Economy and Space 44: 937-953. 
To cite this article: Usher, M. (2019) Territory incognita. Progress in Human Geography, DOI: $10.1177 / 0309132519879492$

Joyce P (2013) The state of freedom: A social history of the British State since 1800. Cambridge, UK: Cambridge University Press.

Kearns G (2009) Geopolitics and empire: The legacy of Halford Mackinder. Oxford: Oxford University Press.

Keighren I M (2006) Bringing geography to the book: Charting the reception of Influences of Geographic Environment. Transactions of the Institute of British Geographers 31(4): 525540.

Keighren I M (2018) History and philosophy of geography III: The haunted, the reviled, and the plural. Progress in Human Geography doi.org/10.1177/0309132518818725

Keighren I M, Abrahamsson C and della Dora V (2012) On canonical geographies. Dialogues in Human Geography 2(3): 296-312.

Kipfer S, Saberi P and Wieditz T (2013) Henri Lefebvre: Debates and controversies. Progress in Human Geography 37(1): 115-134.

Klauser F R (2012) Thinking through territoriality: Introducing Claude Raffestin to Anglophone sociospatial theory. Environment and Planning D: Society and Space 30(1): $106-120$.

Klinke I (2018) Cryptic concrete. Oxford: Wiley-Blackwell

Klinke I and Bassin M (2018) Introduction: Lebensraum and its discontents. Journal of Historical Geography 61: 53-58.

Knutsen T L (2014) Halford J. Mackinder, geopolitics, and the Heartland Thesis. The International History Review 36(5): 835-857.

Koelsch W A (2014) Miss Semple meets the historians: the failed AHA 1907 conference on geography and history and what happened afterwards. Journal of Historical Geography 45: 50-58.

Latour B (2017) Facing Gaia: Eight lectures on the new climatic regime. Cambridge: Polity Press.

Latour B (2018) Down to earth: Politics in the new climatic regime. Cambridge: Polity Press. Lefebvre H (1991) The production of space. Oxford: Blackwell. 
To cite this article: Usher, M. (2019) Territory incognita. Progress in Human Geography, DOI: $10.1177 / 0309132519879492$

Lefebvre H (2003) The urban revolution. Minneapolis, MN: University of Minnesota Press.

Lefebvre H (2009) State, space, world: Selected essays. Minneapolis, MN: University of Minnesota Press.

Lefebvre H (2014) Critique of everyday life: The one-volume edition. London: Verso.

Legg S (2006) Governmentality, congestion and calculation in colonial Delhi. Social \& Cultural Geography 7(5): 709-729.

Legg S (2007) Spaces of colonialism: Delhi's urban governmentalities. Oxford: Blackwell.

Legg S (eds) (2011) Spatiality, sovereignty and Carl Schmitt: Geographies of the Nomos. London: Routledge.

Lehman J (2013) Volumes beyond volumetrics: A response to Simon Dalby's 'The geopolitics of climate change'. Political Geography 37: 51-52.

Loftus A (2015) Violent geographical abstractions. Environment and Planning D: Society and Space 33(2): 366-381.

Loftus A (2018) Political ecology II: Whither the state? Progress in Human Geography doi.org/10.1177/0309132518803421

Macfarlane R (2019) Underland: A deep time journey. London: Hamish Hamilton.

Mackinder H J (1887) On the scope and methods of geography. Proceedings of the Royal Geographical Society and Monthly Record of Geography 9(3):141-174.

Mackinder H J (1890) The physical basis of political geography. Scottish Geographical Magazine 6(2): 78-84.

Mackinder H J (1904) The geographical pivot of history. The Geographical Journal 23(4): 421-437.

MacLeavy J and Harrison J (2010) New State Spatialities: Perspectives on State, Space, and Scalar Geographies. Antipode 42(5): 1037-1046.

Maier C S (2016) Once within borders: Territories of power, wealth, and belonging since 1500. Cambridge, MA: Harvard University Press. 
To cite this article: Usher, M. (2019) Territory incognita. Progress in Human Geography, DOI: $10.1177 / 0309132519879492$

Mamadouh V (1999) Reclaiming geopolitics: Geographers strike back. Geopolitics 4(1): 118138.

Mann G and Wainwright J (2018) Climate leviathan: A political theory of our planetary future. London: Verso.

Marston S A, Jones J P and Woodward K (2005) Human geography without scale. Transactions of the Institute of British Geographers 30(4): 416-432.

Martin L and Secor AJ (2014) Towards a post-mathematical topology. Progress in Human Geography 38(3): 420-438.

Mason M and Khawlie M (2016) Fluid sovereignty: State-nature relations in the Hasbani Basin, Southern Lebanon. Annals of the American Association of Geographers 106(6): 13441359.

Matless D (2016) Landscape and Englishness. London: Reaktion Books.

Melo Zurita M and Munro P (2019) Voluminous territorialisation: Historical contestations over the Yucatan Peninsula's subterranean waterscape. Geoforum 102: 38-47.

Merriman P and Jones R (2017) Nations, materialities and affects. Progress in Human Geography 41(5): 600-617.

Mezzadra S and Neilson B (2013) Border as method, or, the multiplication of labor. Durham, NC: Duke University Press.

Militz E and Schurr C (2016) Affective nationalism: Banalities of belonging in Azerbaijan. Political Geography 54: 54-63.

Minca C (2006) Giorgio Agamben and the new biopolitical Nomos. Geografiska Annaler B 88: 387-403.

Minca C and Rowan R (2016) On Schmitt and space. London: Routledge.

Minghi J (1963) Boundary studies in political geography. Annals of the Association of American Geographers 53(3): 407-428.

Mitchell T (2002) Rule of experts: Egypt, techno-politics, modernity. Berkley, CA: University of California Press.

Mitchell T (2011) Carbon democracy: Political power in the age of oil. London: Verso. 
To cite this article: Usher, M. (2019) Territory incognita. Progress in Human Geography, DOI: $10.1177 / 0309132519879492$

Mol A and Law J (2005) Boundary variations: An introduction. Environment and Planning D: Society and Space 23(5): 637-642.

Moore J (2016) Anthropocene or capitalocene? Nature, history, and the crisis of capitalism. Oakland, CA: PM Press.

Morton T (2016) Dark ecology: For a logic of future coexistence. New York, NY: Columbia University Press

Mukerji C (2009) Impossible engineering: Technology and territoriality on the Canal du Midi. Princeton, NJ: Princeton University Press.

Murphy A B (2012) Entente territorial: Sack and Raffestin on territoriality. Environment and Planning D: Society and Space 30(1): 159-172.

Muscarà L (2005) Territory as a psychosomatic device: Gottmann's kinetic political geography. Geopolitics 10(1): 26-49.

Nail T (2016) Theory of the border. Oxford: Oxford University Press.

Newman D (2003) On borders and power: A theoretical framework. Journal of Borderlands Studies 18(1): 13-25.

Nightingale A J (2018) The socioenvironmental state: Political authority, subjects, and transformative socionatural change in an uncertain world. Environment and Planning E: Nature and Space 1(4): 688-711.

O'Loughlin J (2018) Thirty-five years of political geography and Political Geography: The good, the bad and the ugly. Political Geography 65: 143-151.

Painter J (2010) Rethinking Territory. Antipode 42(5): 1090-1118.

Parenti C (2015) The environment making state: Territory, nature, and value. Antipode 47(4): 829- 848.

Parker G (2000) Ratzel, the French School and the birth of alternative geopolitics. Political Geography 19(8): 957-969.

Peet R (1985) The social origins of environmental determinism. Annals of the Association of American Geographers 75(3): 309-333. 
To cite this article: Usher, M. (2019) Territory incognita. Progress in Human Geography, DOI: $10.1177 / 0309132519879492$

Peloquin C (2013) Locust swarms and the spatial techno-politics of the French Resistance in World War II. Geoforum 49: 103-113.

Peters K, Steinberg P and Stratford E (2018) Territory beyond terra. London: Rowan and Littlefield.

Philo C (2012) A 'new Foucault' with lively implications - or 'the crawfish advances sideways'. Transactions of the Institute of British Geographers 37(4): 496-514.

Pritchard S (2011) Confluence: The nature of technology and the remaking of the Rhône. Cambridge, MA: Harvard University Press.

Protevi J (2013) Life, war, earth: Deleuze and the sciences. Minneapolis, MN: University of Minnesota Press.

Raffestin C (2012) Space, territory, and territoriality. Environment and Planning D: Society and Space 30(1): 121-141.

Ratzel F (1882) Anthropo-Geographie. Stuttgart: Engelhorn.

Ratzel F (1891) Anthropogeographie, vol. II. Stuttgart: Engelhorn.

Ratzel F (1897) Politische geographie. Munchen und Leipzig: R. Oldenbourg.

Ratzel F (1898a) Studies in political areas II: Intellectual, political, and economic effects of large areas [translated by Ellen Churchill Semple]. American Journal of Sociology 3(4): 449463.

Ratzel F (1898b) Studies in political areas III: The small political area [translated by Ellen Churchill Semple]. American Journal of Sociology 4(3): 366-379.

Ratzel F (2018 [1901]) Lebensraum: a biogeographical study [translated by Tul'si (Tuesday) Bhambry]. Journal of Historical Geography 61: 59-80.

Ripley W (1894) Anthropo-Geographie by Friedrich Ratzel. Political Science Quarterly 9 (2): 321-324.

Robbins $P$ (2008) The state in political ecology: A postcard to political geography from the field. In: Cox K, Low M and Robinson J (eds), The SAGE handbook of political geography, London: SAGE Publications, 205-218. 
To cite this article: Usher, M. (2019) Territory incognita. Progress in Human Geography, DOI: $10.1177 / 0309132519879492$

Robertson M (2015) Environmental governance: Political ecology and the state. In: Perreault T, Bridge G and McCarthy J (eds), The Routledge handbook of political ecology, London: Routledge, 457-466.

Rose-Redwood R (2006) Governmentality, geography, and the geo-coded world. Progress in Human Geography 30(4): 469-486.

Rose-Redwood R (2012) With numbers in place: Security, territory, and the production of calculable space. Annals of the Association of American Geographers 102(2): 295-319.

Routledge P (2015) Territorialising movement: The politics of land occupation in Bangladesh. Transactions of the Institute of British Geographers 40(4): 445-463.

Ruggie J (1993) Territoriality and beyond: Problematizing modernity in international relations International Organization 4Х(1): 139-174.

Rutherford S (2007) Green governmentality: insights and opportunities in the study of nature's rule. Progress in Human Geography 31(3): 291-307.

Sack R D (1983) Human Territoriality: A Theory. Annals of the Association of American Geographers 73(1): 55-74.

Sack R D (1986) Human territoriality: Its theory and history. Cambridge: Cambridge University Press.

Saldanha A (2017) Space after Deleuze. London: Bloomsbury.

Sammler K (2019) The rising politics of sea level: Demarcating territory in a vertically relative world. Territory, Politics, Governance doi.org/10.1080/21622671.2019.1632219

Satizábal P and Batterbury S (2018) Fluid geographies: Marine territorialisation and the scaling up of local aquatic epistemologies on the Pacific coast of Columbia. Transactions of the Institute of British Geographers 43(1): 61-78.

Schindler S (2015) Governing the twenty-first century metropolis and transforming territory. Territory, Politics, Governance 3(1):7-26.

Schmitt C (2003) The nomos of the earth. New York, NY: Telos Press.

Scholte J A (2008) Defining globalisation. World Economy 31(11): 1471-1502. 
To cite this article: Usher, M. (2019) Territory incognita. Progress in Human Geography, DOI: $10.1177 / 0309132519879492$

Scott J (1998) Seeing like a state: How certain schemes to improve the human condition have failed. New Haven, CT: Yale University Press.

Secor A (2018) Response to John O'Loughlin. Political Geography 65: 154-155.

Semple E C (1911) Influences of geographic environment, on the basis of Ratzel's system of anthropogeography. New York, NY: Henry Holt.

Sevilla-Buitrago A (2012) Territory and the governmentalisation of social reproduction: Parliamentary enclosure and spatial rationalities in the transition from feudalism to capitalism. Journal of Historical Geography 38(3): 209-219.

Shah N (2012) The territorial trap of the territorial trap: Global transformation and the problem of the state's two territories. International Political Sociology 6: 57-76.

Sibertin-Blanc G (2016) State and politics: Deleuze and Guattari on Marx. South Pasadena, CA: Semiotext(e).

Slesinger I (2018) A cartography of the unknowable: Technology, territory and subterranean agencies in Israel's management of the Gaza tunnels. Geopolitics doi.org/10.1080/14650045.2017.1399878

Smith R G (2003) World city topologies. Progress in Human Geography 27(5): 561-582.

Sneddon C (2015) Concrete revolution: Dams, Cold War geopolitics, and the US Bureau of Reclamation. Chicago, IL: Chicago University Press.

Solot M (1986) Carl Sauer and cultural evolution. Annals of the Association of American Geographers 76(4): 508-520.

Squire R (2015) Rock, water, air and fire: Foregrounding the elements in the Gibraltar-Spain dispute. Environment and Planning D: Society and Space 34(3): 545-563.

Squire R and Dodds K (2019) Introduction to the special issue: Subterranean geopolitics. Geopolitics doi.org/10.1080/14650045.2019.1609453

Steinberg P (2009) Sovereignty, territory, and the mapping of mobility: A view from the outside. Annals of the Association of American Geographers 99(3): 467-495. 
To cite this article: Usher, M. (2019) Territory incognita. Progress in Human Geography, DOI: $10.1177 / 0309132519879492$

Steinberg P and Kristoffersen B (2017) 'The ice edge is lost...nature moved it': Mapping ice as state practice in the Canadian and Norwegian North. Transactions of the Institute of British Geographers 42: 625-641.

Steinberg P and Peters K (2015) Wet ontologies, fluid spaces: Giving depth to volume through oceanic thinking. Environment and Planning D: Society and Space 33(2): 247-264.

Swyngedouw E (1992) Territorial Organization and the Space/Technology Nexus. Transactions of the Institute of British Geographers 17(4): 417.

Swyngedouw E (2000) Authoritarian governance, power, and the politics of rescaling. Environment and Planning D: Society and Space 18(1): 63-76.

Swyngedouw E (2015) Liquid power: Contested hydro-modernities in twentieth-century Spain. Cambridge, MA: MIT Press.

Swyngedouw E and Ernstson H (2018) Interrupting the Anthropo-obScene: Immunobiopolitics and depoliticizing ontologies in the Anthropocene. Theory, Culture \& Society 35(6): $3-30$.

Taylor P J (1994) The state as container: territoriality in the modern world-system. Progress in Human Geography 18(2): 151-162.

Taylor P J (2000) Embedded statism and the social sciences 2: Geographies (and metageographies) in globalization. Environment and Planning A: Economy and Space 32(6): $1105-1114$.

Teschke B (2003) The myth of 1648: Class, geopolitics, and the making of modern international relations. London: Verso.

Tolia-Kelly D P (2013) The geographies of cultural geography III: Material geographies, vibrant matters and risking surface geographies. Progress in Human Geography 37(1): 153160.

Tuathail G Ó (1999) Borderless worlds? Problematising discourses of deterritorialisation. Geopolitics 4(2): 139-154.

Turner B L (2002) Contested identities: Human-environment geography and disciplinary implications in a restructuring academy. Annals of the Association of American Geographers 92: 52-74. 
To cite this article: Usher, M. (2019) Territory incognita. Progress in Human Geography, DOI: $10.1177 / 0309132519879492$

Uitermark J (2015) The particularities of territory. Territory, Politics, Governance 3(1): 1-6.

Usher M (2018) Conduct of conduits: Engineering, desire and government through the enclosure and exposure of urban water. International Journal of Urban and Regional Research 42: 315-333.

Usher M (2019) Desali-nation: Techno-diplomacy and hydraulic state restructuring through reverse osmosis membranes in Singapore. Transactions of the Institute of British Geographers 44(1): 110-124.

Valdivia G (2015) Oil frictions and the subterranean geopolitics of energy regionalisms. Environment and Planning A: Economy and Space 47(7): 1422-1439.

Van Houtum H (2005) The geopolitics of borders and boundaries. Geopolitics 10(4): 672679.

Vela-Almeida D (2018) Territorial partitions, the production of mining territory and the building of a post-neoliberal and plurinational state in Ecuador. Political Geography 62: 126136.

Verne J (2017) The neglected "gift" of Ratzel for/from the Indian Ocean: Thoughts on mobilities, materialities and relational spaces. Geographica He/vetica 72: 85-92.

Weber M (1978) Economy and society: An outline of interpretative sociology. Volume I. Berkley, CA: University of California Press.

Weizman I (2007) Hollow land: Israel's architecture of occupation. London: Verso.

Whitehead M, Jones R and Jones M (2007) The nature of the state: excavating the political ecologies of the modern state. Oxford: Oxford University Press.

Whitehead M (2009) State, science and the skies. Oxford: Wiley-Blackwell.

Williams A (2013) Re-orientating vertical geopolitics. Geopolitics 18(1): 225-246.

Wilson J (2013) 'The Devastating Conquest of the Lived by the Conceived': The Concept of Abstract Space in the Work of Henri Lefebvre. Space and Culture 16(3): 364-380.

Wilson J (2014) The violence of abstract space: Contested regional developments in Southern Mexico. International Journal of Urban and Regional Research 38(2): 516-538. 
To cite this article: Usher, M. (2019) Territory incognita. Progress in Human Geography, DOI: $10.1177 / 0309132519879492$

Wirth C (2016) Securing the seas, securing the state: Hope, danger and the politics of order in the Asia-Pacific. Political Geography 53: 76-85.

Woodward K (2014) Affect, state theory, and the politics of confusion. Political Geography 41: 21-31.

Yusoff K (2016) Anthropogenesis: Origins and endings in the Anthropocene. Theory, Culture \& Society 33(2): 3-28.

Yusoff K (2017) Geosocial strata. Theory, Culture \& Society 34(2-3): 105-127.

Zimmerer K S (2010) Retrospective on nature-society geography: Tracing trajectories (1911-2010) and reflecting on translations. Annals of the Association of American Geographers 100(5):1076-1094. 